\title{
Mineralogy of Ti-bearing, Al-deficient tourmaline assemblages associated with lamprophyre dikes near the O'Grady Batholith, Northwest Territories, Canada
}

\author{
Emily D. SCRIBNER ${ }^{*}$, Lee A. GROAT ${ }^{1}$, Jan CEMPÍREK² \\ ${ }^{1}$ Department of Earth, Ocean and Atmospheric Sciences, University of British Columbia, Vancouver, British Columbia V6T 1Z4, Canada; \\ escribne@eoas.ubc.ca \\ ${ }^{2}$ Department of Geological Sciences, Faculty of Science, Masaryk University, Kotlářská 2, 61137 Brno, Czech Republic \\ * Corresponding author
}

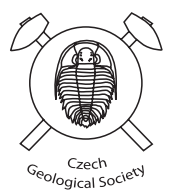

Calc-alkaline lamprophyre dikes are hosted by tourmalinized metasedimentary rocks in the Northwest Territories, Canada. Some of these lamprophyre dikes are cross-cut by aplite and pegmatite dikes, as well as tourmaline-bearing quartz veins that were all derived from the nearby granitic O'Grady Batholith.

The lamprophyre dikes are composed of actinolite to magnesio-hornblende, plagioclase, K-feldspar and quartz with minor phlogopite (up to 4.13 wt. \% $\mathrm{TiO}_{2}$ ), titanite, apatite, pyrite, allanite-(Ce), and zircon. A zone near the margin of one of the dikes has been altered to tourmaline associated with actinolite to magnesio-hornblende, clinochlore, titanite and quartz, with minor clinopyroxene and apatite. Two generations of tourmaline are recognized: Tur I occurs in quartz at the margin of the dike and Tur II forms a massive aggregate with common inclusions of other minerals in an altered lamprophyre zone near the margin of the dike. The vast majority of the analyzed tourmaline is Al-deficient, with less than 6 apfu $\mathrm{Al}$ at the $Z$ site (on average 5.691 apfu in Tur I and 5.601 apfu in Tur II). Tur I is mostly dravite with uvite, plus minor feruvite and fluor-uvite, while Tur II contains a greater proportion uvite, feruvite, and fluor-uvite. The most evolved tourmaline compositions observed are feruvite with up to $2.17 \mathrm{wt}$. $\% \mathrm{TiO}_{2}$, and fluor-uvite with up to $0.84 \mathrm{wt}$. $\%$ F. The tourmaline composition reflects the unique geochemical environment in which it crystallized; from Tur I to Tur II, tourmaline becomes richer in $\mathrm{Ca}-, \mathrm{Fe}-$, and $\mathrm{Ti}$, presumably due to the reaction of B-bearing fluids with the Al-poor, $\mathrm{Ca}-\mathrm{Mg}-\mathrm{Fe}$-, and Ti-bearing minerals in the lamprophyre dike. The high $\mathrm{F}$ contents of some tourmaline species suggest that it crystallized from fluids derived from the aplite and pegmatite dikes.

Keywords: dravite, uvite, feruvite, fluor-uvite, lamprophyre dikes, O'Grady Batholith

Received: 4 October, 2017; accepted: 1 June, 2018; handling editor: M. Novák

The online version of this article (doi: 10.3190/jgeosci.259) contains supplementary electronic material.

\section{Introduction}

Tourmaline-supergroup minerals are complex borosilicates that occur in a wide variety of host environments. Tourmaline has been extensively studied, in part because of its ability to incorporate numerous elements into its crystal structure, making it an ideal monitor of its local environment (van Hinsberg et al. 2011).

Mineralogical studies related to the O'Grady Batholith, a metaluminous composite intrusion that is a member of the Selwyn Plutonic Suite in the Northwest Territories, Canada, have focused on pegmatite dikes that occur both within the Batholith and in the country rocks surrounding it (e.g., Groat and Ercit 1996; Ercit et al. 2003; Scribner et al. 2014). During field work in 2013, lamprophyre dikes were discovered near the O'Grady Batholith in the Nááts'ihch'oh National Park Reserve, Northwest Territories, Canada (6246'8.33" N, 128 56'9.07" W; Fig. 1).
Upon further examination of the samples, tourmaline was found along the margin of one of the lamprophyre dikes and in an altered lamprophyre zone near its margin. The study area also contains aplite dikes, pegmatite dikes, and late-stage tourmaline-bearing quartz veins, all of which are hosted by metasedimentary rocks. Tourmaline is ubiquitous in the study area, occurring within, or at the margin of, nearly all units. The host rocks are almost completely metasomatized to tourmaline and quartz.

The goals of this study were to characterize the mineralogy of the newly discovered lamprophyre dikes and the associated tourmaline. Furthermore, having recognized that the association of tourmaline with a lamprophyre dike is unusual, we studied the influence of the lamprophyre dike on the composition of tourmaline. This paper presents detailed chemical analyses of minerals in the lamprophyre dikes and the tourmaline that occurs along the margin of one of these dikes. 


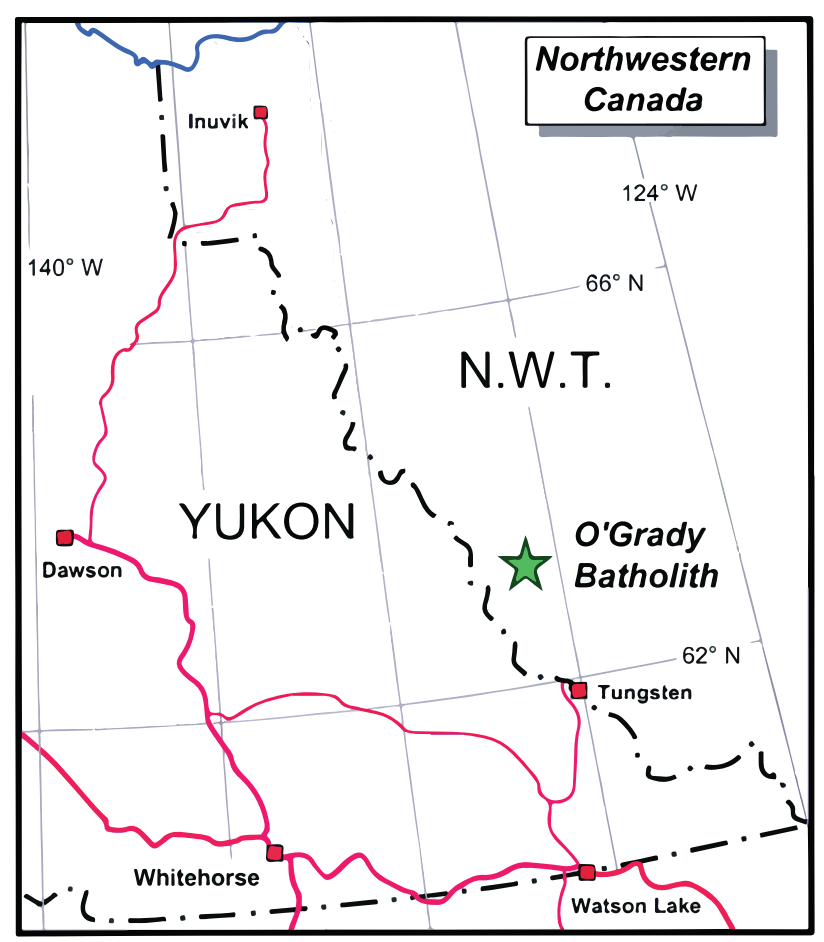

Fig. 1 Location of the O'Grady Batholith in the Northwest Territories (N.W.T.) (Ercit et al. 2003).

\section{Geological setting}

The study area lies within the Selwyn Basin that covers an area of $c .700 \times 200 \mathrm{~km}$ in the central Yukon Territory and southwestern Northwest Territories (Figs 1-2). The basin is defined by Neoproterozoic to Middle Devonian slope-to-basin facies sequences that are overlain by Mississippian to Jurassic shelf and basinal strata in isolated occurrences (Gordey and Anderson 1993; Mair et al. 2006). The lamprophyre dikes and other intrusive rocks of the O'Grady Batholith are hosted in weakly metamorphosed sedimentary rocks of the Mount Christie Fm. that are Mississippian to Permian in age (Gordey and Anderson 1993). Small- to large-scale northwest-trending folds were produced by the regional deformation that occurred from the Jurassic to the Cretaceous (Gordey and Anderson 1993).

During a mid-Cretaceous period of granitic magmatism, the Selwyn Plutonic Suite was emplaced at an epizonal to mesozonal depth. The Selwyn Plutonic Suite has been subdivided into the Tombstone Suite, Tungsten Suite, and Tay River Suite (Gordey and Anderson 1993). The Tombstone Suite has considerable lithological variation, but hornblende-biotite granodiorite and quartz monzonite are the most common phases. The Tungsten Suite has similar characteristics to the Tombstone Suite but has a greater proportion of peraluminous two-mica granites. Finally, the Tay River Suite is dominated by peraluminous two-mica monzogranites (Hart et al. 2000).
Granitic pegmatites are associated with all members of the Selwyn Plutonic Suite (Gordey and Anderson 1993).

\subsection{O'Grady Batholith}

The O'Grady Batholith, part of the Tombstone Suite, is a composite intrusion that is hosted by variably hornfelsed shale, silty shale, and minor chert of the Mount Christie Fm. (Gordey and Anderson 1993) (Fig. 2). The majority of the Batholith is composed of a Kfs-phyric hornblende granite (hornblende quartz syenite of Gordey and Anderson 1993) that grades, via a foliated transitional phase, to an equigranular, hornblende-biotite granodiorite on the margins. The study area is underlain by the megacrystic hornblende granite phase of the O'Grady Batholith (K-Ar hornblende age of $95 \pm 1 \mathrm{Ma}$; Hunt and Roddick 1987).

\subsection{Aplite and pegmatite dikes, quartz veins}

Aplite and pegmatite dikes are late-stage differentiates of the O'Grady Batholith. The aplite dikes are $0.2-1 \mathrm{~m}$ thick and composed of quartz, K-feldspar, plagioclase, and tourmaline, with lesser amounts of mica, calcite, and zircon. Tourmaline in the aplite dikes is fluor-schorl with minor zones of schorl. Fluorine reaches a maximum content of 1.30 wt. \% F $(0.706$ apfu $)$ in the core of a crystal (Scribner 2014). The pegmatite dikes are mostly 20-30 $\mathrm{cm}$ thick but some reach $1 \mathrm{~m}$ in thickness. They are composed of quartz, albite, muscovite, and tourmaline, with lesser amounts of K-feldspar, calcite, and apatite. Tourmaline in the pegmatite dikes has foitite cores and schorl rims. The rims have a high $\mathrm{F}$ content and can reach fluorschorl (up to 1.03 wt. \% F; 0.544 apfu) (Scribner 2014).

The aplite dikes, pegmatite dikes, and lamprophyre dikes are all hosted by the metasomatized sedimentary host rocks of the Mount Christie Fm. The host rocks are composed almost entirely of tourmaline and quartz. Tourmaline is mainly dravite with small zones of schorl. In contrast to the aplite and pegmatite dikes, the F content of tourmaline in the host rocks is low with a maximum of 0.25 wt. \% (0.132 apfu) in dravite (Scribner 2014).

Quartz veins, often tourmaline-bearing, cross-cut all units in the study area. Tourmaline growing into a quartz vein that cross-cuts the host rock has uvite cores and dravite rims. This tourmaline also has a low F content, reaching a maximum of $0.42 \mathrm{wt} . \%(0.224 \mathrm{apfu})$ in dravite (Scribner 2014).

\subsection{Lamprophyre dikes}

Anderson (1983) identified lamprophyre dikes associated with the Northern Nahanni Pluton (part of the Tay River Suite), which is located c. $14.5 \mathrm{~km}$ E of the study area. The dikes were described as coeval with the other aplite 
Fig. 2 Geological map of the O'Grady Batholith (modified from Gordey 1992). The yellow star marks the location of the studied lamprophyre dikes. In this area, sedimentary rocks of the Mount Christie Fm. have been metasomatized almost entirely to tourmaline and quartz. The map units are as follows: (1) Rabbitkettle Fm.: nodular limestone; (2) Broken Skull Fm.: dolostone, limestone, local basal member of dolostone and sandstone; (3) Haywire Fm.: locally cherty dolostone, rare amygdaloidal basalt and tuff, basal member of dolostone, quartz arenite, and mudstone; (4) Sapper Fm.: limestone, silty limestone; (5) Funeral Fm.: silty limestone; (6) Portrait Lake Fm.: chert-quartz wacke and massive pebbly limestone, siliceous shale and chert; (7) Prevost Fm.: chert-quartz sandstone, chert-pebble conglomerate and minor shale, shale and minor chertquartz sandstone; (8) Tsichu Fm.: resistant, thick-bedded quartz arenite, minor shale; (9) Mount Christie Fm.: shale, siltstone, and chert, minor quartz sandstone; (10) Jones Lake Fm.: shale, ripple cross-laminated siltstone and sandstone; (11) Selwyn Plutonic Suite: hornblende-biotite granite and granodiorite; (12) Unconsolidated glacial and alluvial deposits.

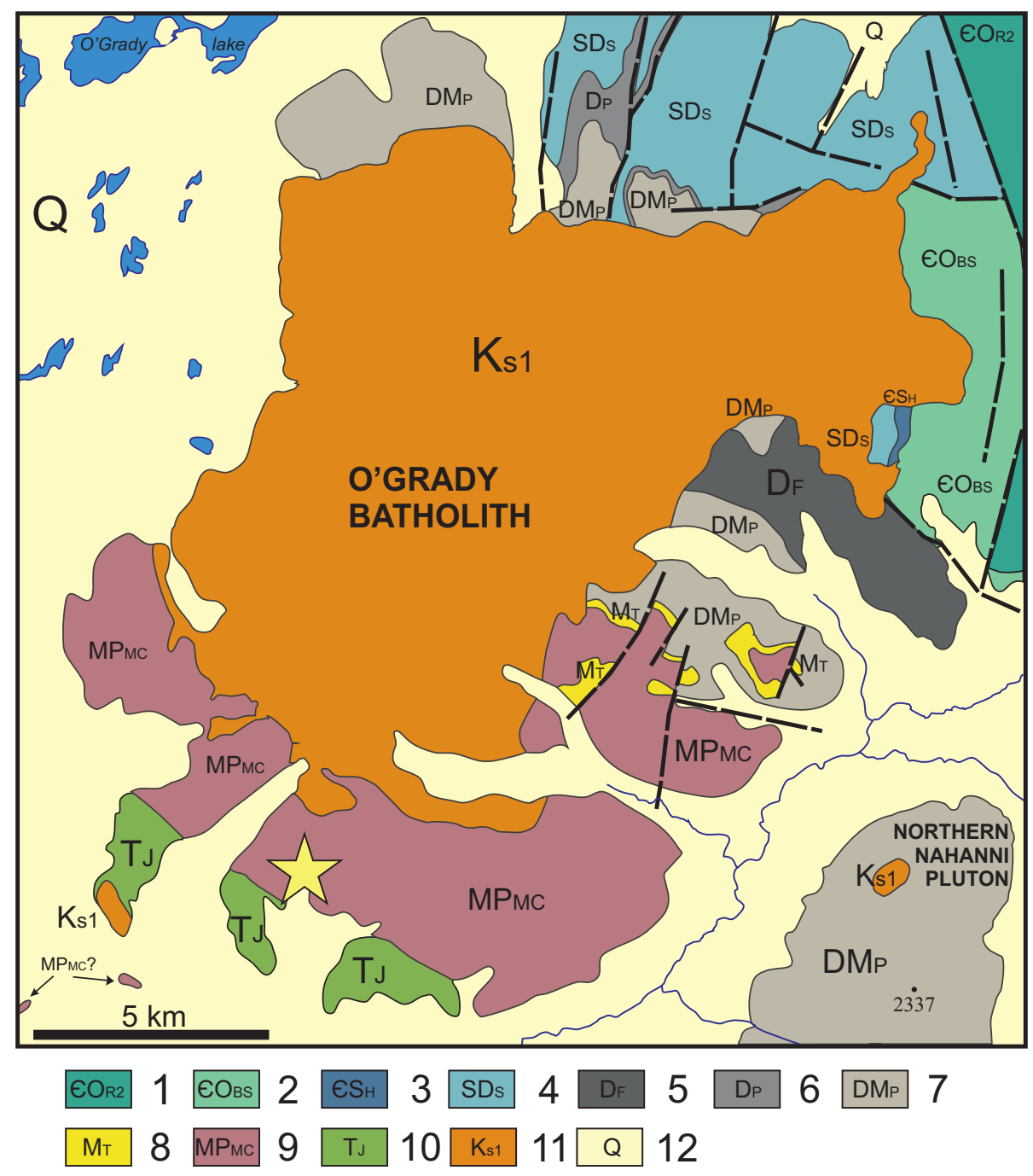

analyzed using a CAMECA SX-50 electron microprobe operating in wavelength-dispersion mode at the University of British Columbia. Data reduction was done using the 'PAP' $\phi(\rho Z)$ method (Pouchou and Pichoir 1985). The following analytical conditions were used: acceleration voltage $15 \mathrm{kV}$, beam current $20 \mathrm{nA}$ (10 nA for chlorite and mica), peak counting time $20 \mathrm{~s}$ (40 s for $\mathrm{F}$ in tourmaline and amphibole; $60 \mathrm{~s}$ for $\mathrm{F}$ and $40 \mathrm{~s}$ for $\mathrm{Cl}$ in chlorite; 40 $\mathrm{S}$ for $\mathrm{F}, \mathrm{Cl}, \mathrm{Rb}$, and $\mathrm{Cs}$ in mica), background count time $10 \mathrm{~s}$ (20 s for $\mathrm{F}$ in tourmaline and amphibole; $30 \mathrm{~s}$ for $\mathrm{F}$ and $20 \mathrm{~s}$ for $\mathrm{Cl}$ in chlorite; $20 \mathrm{~s}$ for $\mathrm{F}, \mathrm{Cl}, \mathrm{Rb}$, and $\mathrm{Cs}$ in mica), spot diameter $5 \mu \mathrm{m}$ (10 $\mu \mathrm{m}$ for chlorite and mica). The following standards were used for each mineral (all X-ray lines were $K_{\alpha}$ unless otherwise stated): amphibole (phlogopite, F, TAP; albite, Na, TAP; kyanite, Al, TAP; diopside Mg, Si, TAP; diopside, Ca, PET; scapolite, Cl, PET; orthoclase, $\mathrm{K}$, PET; rutile, Ti, PET; magnesiochromite, $\mathrm{Cr}$, LIF; rhodonite, Mn, LIF; fayalite, Fe, LIF; Ni-olivine, $\mathrm{Ni}, \mathrm{LIF}$ ); feldspar (albite, Na, TAP; anorthite, Al, TAP; diopside, Mg, TAP; anorthite, Si, TAP; anorthite, Ca, PET; orthoclase, K, PET; rhodonite, Mn, LIF; fayalite, Fe, LIF);
The compositions of amphibole-supergroup minerals, feldspars, chlorite-group minerals, titanite, and micas were 


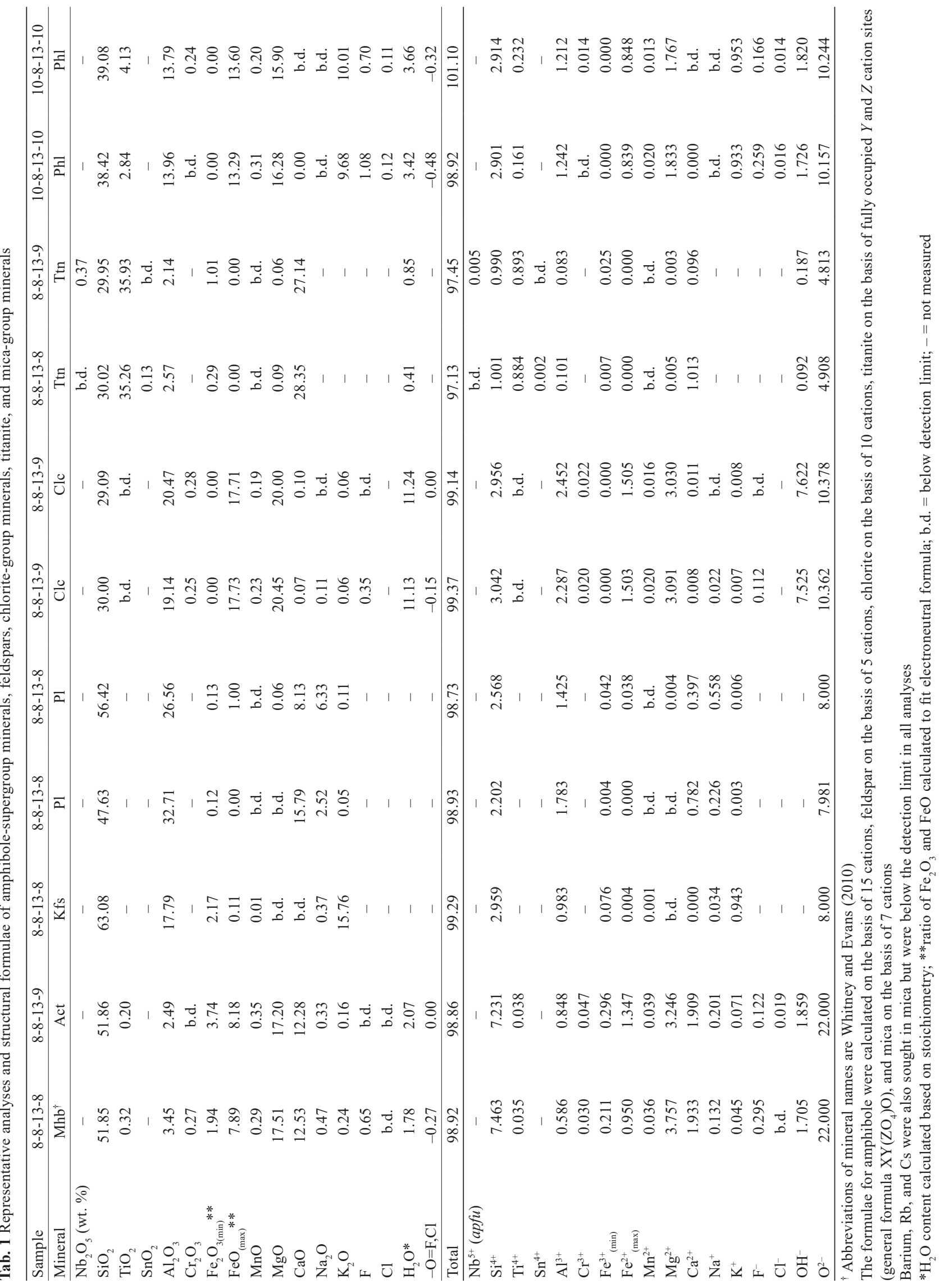


chlorite (phlogopite, F, Mg, Si, TAP; phlogopite, K, PET; albite, Na, TAP; kyanite, Al, TAP; scapolite, Cl, PET; diopside, Ca, PET; rutile, Ti, PET; magnesiochromite, Cr, LIF; rhodonite, Mn, LIF; fayalite, Fe, LIF); titanite (diopside, $\mathrm{Mg}$, Si, TAP; diopside, Ca, PET; kyanite, Al, TAP; rutile, Ti, PET; rhodonite, Mn, LIF; fayalite, Fe, LIF; columbite, $\mathrm{Nb}, \mathrm{PET}$; cassiterite, Sn, PET); mica (phlogopite, F, Mg, $\mathrm{Si}$, TAP; phlogopite, K, PET; albite, Na, TAP; kyanite, Al, TAP; scapolite, Cl, PET; diopside, Ca, PET; rutile, Ti, PET; magnesiochromite, Cr, LIF; rhodonite, Mn, LIF; fayalite, $\mathrm{Fe}$, LIF; rubidium titanyl phosphate, $\mathrm{Rb} L_{\alpha}$, TAP; pollucite, $\mathrm{Cs} L_{\alpha}$, PET; barite, $\mathrm{Ba} L_{\alpha}$, LIF).

Tourmaline was analyzed at Masaryk University, Brno (Czech Republic) using a Cameca SX-100 instrument operating in wavelength-dispersion mode. The following analytical conditions were applied: acceleration voltage $15 \mathrm{kV}$, beam current $10 \mathrm{nA}$, spot diameter $5 \mu \mathrm{m}$. The following standards were used (all X-ray lines were $K_{\alpha}$ ): albite, Na, TAP; sanidine, Si, Al, TAP; sanidine, K, PET; pyrope, Mg, TAP; titanite, Ti, LPET; chromite, Cr, LPET; vanadinite, $\mathrm{Cl}$, LPET; fluorapatite, $\mathrm{P}$, LPET; wollastonite, $\mathrm{Ca}$, PET; almandine, Fe, LLIF; spessartine, Mn, LLIF; $\mathrm{ScVO}_{4}$, V, LLIF; gahnite, Zn, LLIF; topaz, F, PC1.

Amphibole formulae were calculated on the basis of 15 cations at the $T, C$ and $B$ sites. Feldspar formulae were calculated on the basis of 5 cations, chlorites on the basis of 10 cations, and mica on the basis of 7 cations. Titanite formulae were calculated on the basis of fully occupied $Y$ and $Z$ cation sites (general formula $\mathrm{XY}\left(\mathrm{ZO}_{4}\right) \mathrm{O}$ ). Tourmaline formulae were calculated on the basis of $15 Y+Z+T$ cations [general formula $\mathrm{XY}_{3} \mathrm{Z}_{6}\left(\mathrm{~T}_{6} \mathrm{O}_{18}\right)\left(\mathrm{BO}_{3}\right)_{3} \mathrm{~V}_{3} \mathrm{~W}$ ] with boron content fixed at $3 \mathrm{apfu}$. This assumes no Li or vacancies at the $Y$ site and no ${ }^{[4]} \mathrm{B}$ at the $T$ site. The absence of $\mathrm{Li}$ at the $Y$ site is assumed valid because of the lack of any Li-enriched minerals in all examined units. The assumption that the $B$ site is fully occupied by B and that there is no B in the tetrahedral site was deemed to be valid for most occurrences of tourmaline (Hawthorne and Dirlam 2011). Furthermore, the uncommon tourmaline specimens that contain tetrahedral $\mathrm{B}$ are Al-rich (e.g., Ertl et al. 2006), whereas all tourmaline species analyzed in this study are Al-deficient.

The $\mathrm{H}_{2} \mathrm{O}$ contents of amphibole, chlorite, titanite, mica, and tourmaline was calculated based on ideal stoichiometry. The minimum $\mathrm{Fe}_{2} \mathrm{O}_{3}$ contents in all analyzed minerals were calculated to fit the electroneutral formula.

\section{Results}

\subsection{Petrology and mineral chemistry of the lamprophyre dikes}

The lamprophyre (specifically spessartite) dikes trend north-south, range from 2-6 $\mathrm{m}$ in width, and are hosted by metasedimentary rocks. They are composed of amphibole, plagioclase, K-feldspar, and quartz, with minor titanite, and rare diopside, apatite, pyrite, allanite-(Ce), and zircon. Phlogopite is common in some dikes and rare in others. A zone near the margin of one of the lamprophyre dikes that has been altered to tourmaline also contains amphibole, chlorite, titanite, and quartz, with minor clinopyroxene and apatite.

Amphibole is the main matrix mineral and also occurs as aggregates of elongated grains up to $2 \mathrm{~mm}$ across. Plagioclase also occurs in the matrix and rarely as subhedral phenocrysts. Other matrix minerals include K-feldspar, quartz, and titanite, while diopside and apatite are rarer and form small $(<50 \mu \mathrm{m})$ subhedral grains that are disseminated throughout. Pyrite is variable in abundance: in some dikes it can be distinguished in hand sample while in others it occurs in trace amounts. When present, biotite forms large (1-2 $\mathrm{mm}$ long), anhedral phenocrysts that have been partially resorbed, and smaller $(<1 \mathrm{~mm}$ long) platy crystals in the matrix, both of which are deep red-brown in color.

The main minerals in the lamprophyre dikes were analyzed using EMPA. Representative compositions can be found in Tab. 1, and all analyses are provided in the Electronic Supplementary Material on the Journal of Geosciences website.

Amphiboles show $\mathrm{Mg} /(\mathrm{Fe}+\mathrm{Mg})$ of $0.62-0.79$ both in the unaltered dikes and the tourmalinized zone in one of the dikes. They are calcic amphiboles with minor amounts of $\mathrm{Na}+\mathrm{K}\left(\max .0 .20 a p f u^{\mathrm{A}} \mathrm{Na}, 0.07 a p f u^{\mathrm{A}} \mathrm{K}\right)$, classifying them as actinolite to magnesio-hornblende (Fig. 3a). The compositional variability reflects mainly the Tschermak's substitution $\left({ }^{\mathrm{C}} \mathrm{R}^{3+}+{ }^{\mathrm{T}} \mathrm{Al}\right)\left({ }^{\mathrm{C}} \mathrm{R}^{2+}+{ }^{\mathrm{T}} \mathrm{Si}\right)_{-1}$ combined with the $\left({ }^{\mathrm{A}} \mathrm{Na}+{ }^{\mathrm{T}} \mathrm{Al}\right)\left({ }^{\mathrm{A}} \square+{ }^{\mathrm{T}} \mathrm{Si}\right)_{-1}$ exchange vector approximately in 1:1 ratio, resulting in a general trend towards pargasite and heterovalent substitution $\left({ }^{\mathrm{A}} \mathrm{Na}+\right.$ $\left.{ }^{\mathrm{C}} \mathrm{R}^{3+}+{ }^{\mathrm{T}} \mathrm{Al}_{2}\right)\left({ }^{\mathrm{A}} \square+{ }^{\mathrm{C}} \mathrm{R}^{2+}+{ }^{\mathrm{T}} \mathrm{Si}_{2}\right)_{-1}$ (Fig. 3b).

Plagioclase varies in composition from $\mathrm{An}_{92} \mathrm{Or}_{6} \mathrm{Ab}_{2}$ to $\mathrm{Ab}_{58} \mathrm{An}_{41} \mathrm{Or}_{1} . K$-feldspar is almost pure end-member $\left(\mathrm{Or}_{97} \mathrm{An}_{3} \mathrm{Ab}_{0}\right)$ but also contains up to 2.17 wt. $\% \mathrm{Fe}_{2} \mathrm{O}_{3}$ (0.076 apfu $\mathrm{Fe}^{3+}$ ).

All analyzed chlorite was clinochlore $[\mathrm{Mg} /(\mathrm{Fe}+\mathrm{Mg})$ $=0.61-0.70]$ with octahedral $\mathrm{Al}$ up to $1.41 \mathrm{apfu}$, and trace amounts of Mn (up to 0.03 apfu), Cr (up to 0.03 $a p f u$ ), and F (up to $0.11 a p f u$ ). Titanite occurs in both the main part of the dikes and within the tourmalinized zone as anhedral grains $>100 \mu \mathrm{m}$ long. It contains minor $\mathrm{Al}$ (up to 2.57 wt. $\% \mathrm{Al}_{2} \mathrm{O}_{3} ; 1.01$ apfu $\mathrm{Al}$ ) and $\mathrm{Fe}^{3+}$ (up to 1.01 wt. $\% \mathrm{Fe}_{2} \mathrm{O}_{3} ; 0.025$ apfu $\left.\mathrm{Fe}^{3+}\right)$ due to the substitution $\mathrm{R}^{3+}(\mathrm{OH}, \mathrm{F}) \leftrightarrow \mathrm{TiO}$ (Cempírek et al. 2008), whereas other substituents $(\mathrm{Nb}, \mathrm{Sn}, \mathrm{Mg}, \mathrm{Mn})$ are close to their detection limits.

All analyzed biotite (15 analyses on 10 grains) is phlogopite enriched in $\mathrm{Ti}$, containing a maximum of 
4.13 wt. $\% \mathrm{TiO}_{2}(0.232$ apfu $\mathrm{Ti})$ with an average of 3.34 wt. $\% \mathrm{TiO}_{2}(0.189$ apfu $\mathrm{Ti})$. It can also be slightly enriched in $\mathrm{F}$, containing up to $1.08 \mathrm{wt} . \% \mathrm{~F}(0.259 \mathrm{apfu})$ with an average of 0.67 wt. $\% \mathrm{~F}(0.158 a p f u)$.

\subsection{Tourmaline}

Two textural generations of tourmaline associated with one of the lamprophyre dikes are recognized: Tur I occurs with quartz as subhedral grains up to $5 \mathrm{~mm}$ across at the margin of the lamprophyre dike whereas Tur II forms a massive aggregate with common inclusions of other minerals in an altered lamprophyre zone near the margin of the dike (Figs 4-5). The composition of both
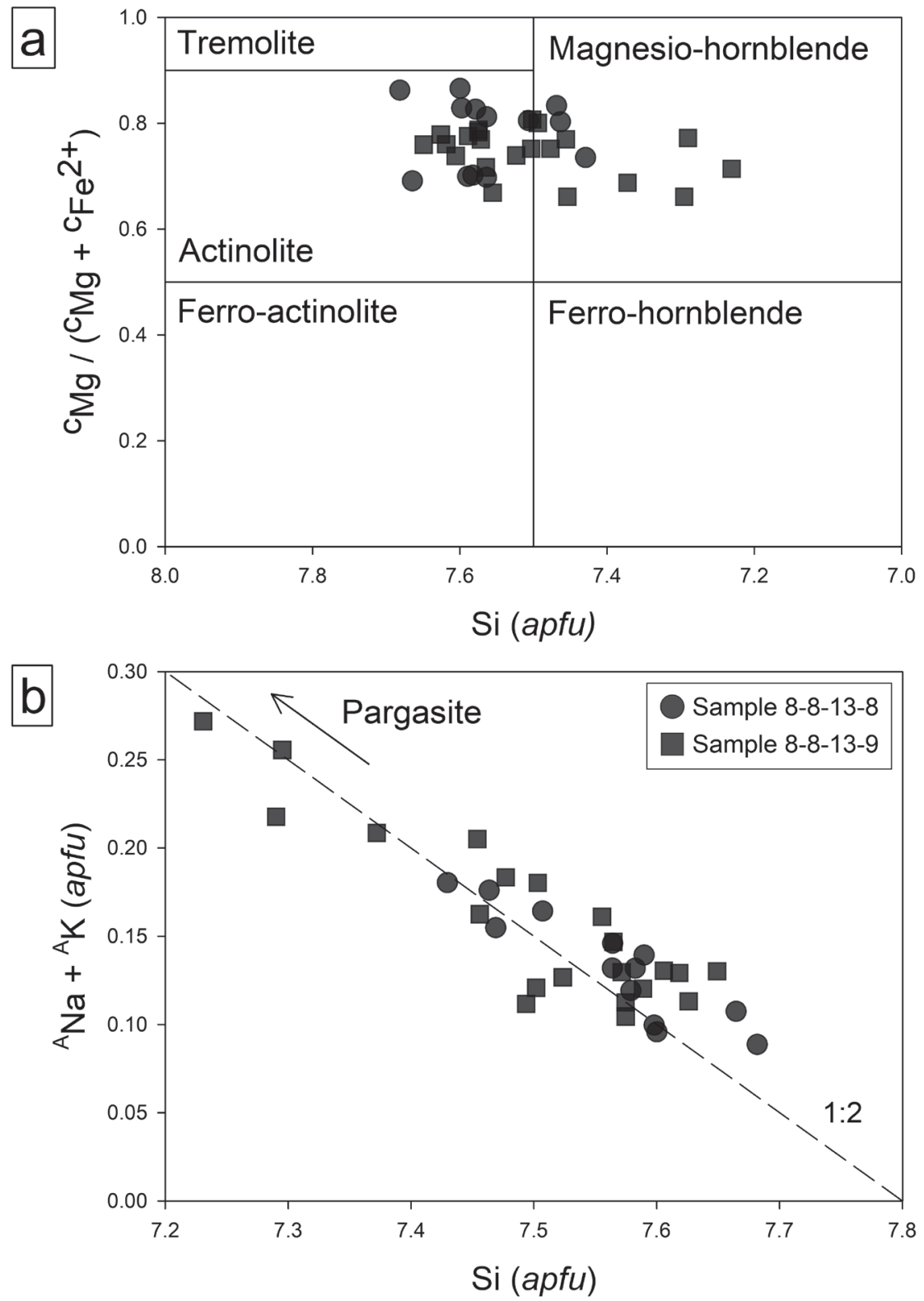

generations is highly variable (Tab. 2). Tur I is mainly pale brown-green in color in plane-polarized light with patchy chemical zoning. It also contains small dark brown zones that tend to be more prominent closer to the margin of the dike (Fig. 5). The composition of Tur I is mostly $\mathrm{Ca},{ }^{\mathrm{w}} \mathrm{O}$ - rich dravite with small patches of feruvite and fluor-uvite; one analytical spot reaches oxy-dravite (Figs 6-7). Tur I also contains small dark brown patches of Fe-rich uvite and feruvite. Some grains of Tur I are zoned with pale blue dravite cores, a darker blue-green intermediate uvite zone, and pale blue dravite rims (Fig. 5). An oxy-dominant species (oxy-dravite) occurs at the outermost rim of a poorly-zoned crystal of Tur I. Tur II has partially replaced the lamprophyre dike (Fig. 5) and frequently encloses grains of actinolite to magnesiohornblende, clinochlore, titanite, and quartz (+ diopside, apatite). Dravite is still a common constituent of Tur II, but it contains more patches of uvite, feruvite, and fluor-uvite than Tur I (Figs 6-7).

The compositions of the two tourmaline types are very similar, but from Tur I to Tur II there is generally a slight increase in $\mathrm{Ca} /(\mathrm{Ca}+\mathrm{Na})$ and in $\mathrm{F} / \mathrm{OH}$, corresponding to a shift from more alkali-group tourmaline in Tur I to more calcic-group tourmaline in Tur II (Fig. 6a). $X$ site vacancy is low in both tourmaline generations, but is highest in dravite from Tur I (0.176 apfu). Fluorine and calculated $\mathrm{O}^{2-}$ increase at the $W$ site, with a maximum 0.447 apfu $\mathrm{F}$ ( 0.84 wt. \% F) in fluor-uvite from Tur II (Fig. 6b).

Overall, $\mathrm{Mg} /\left(\mathrm{Mg}+\mathrm{Fe}^{2+}\right)$ decreases slightly from Tur I to Tur II, but many species in Tur II are still Mg-dominant (Fig. 6c). All analyzed tourmalines are Al-poor, and $\mathrm{Al}$ content generally decreases from Tur I to Tur II, consistent with the observed negative correlation between $\mathrm{Al}$ and $\mathrm{Ca} /(\mathrm{Ca}+\mathrm{Na})$ (Fig. 7a). The highest $\mathrm{Al}$ (6.146

Fig. 3 Plots showing the compositional variation of amphibole-supergroup minerals: $\mathbf{a}$-Classification diagram of calcium amphiboles (Leake et al. 2004); b - Substitution diagram showing $\mathrm{Si}$ vs. $\mathrm{Na}+\mathrm{K}$ at the $A$ site $(a p f u)$. 


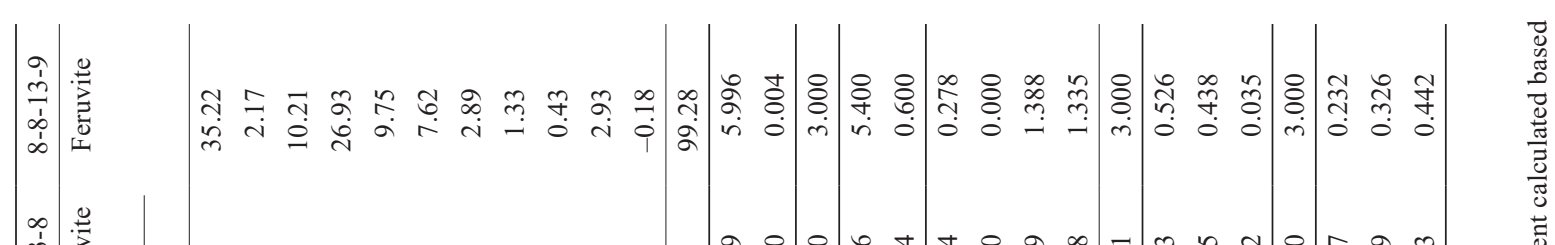

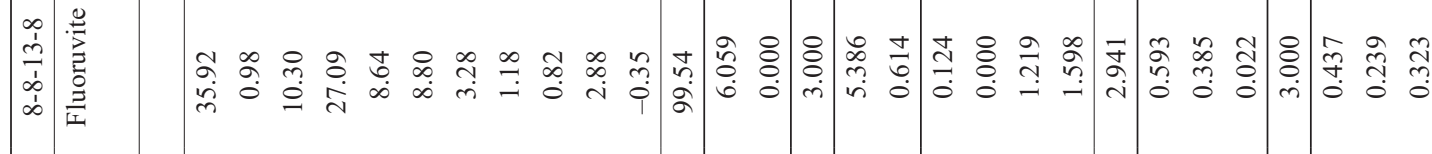

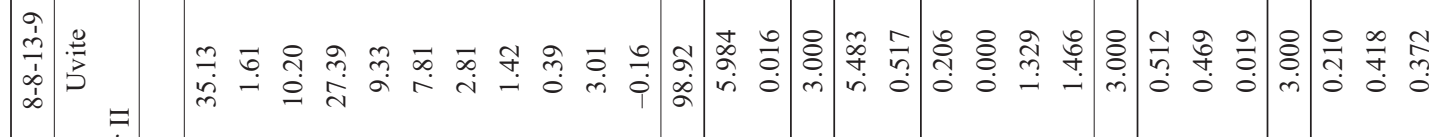

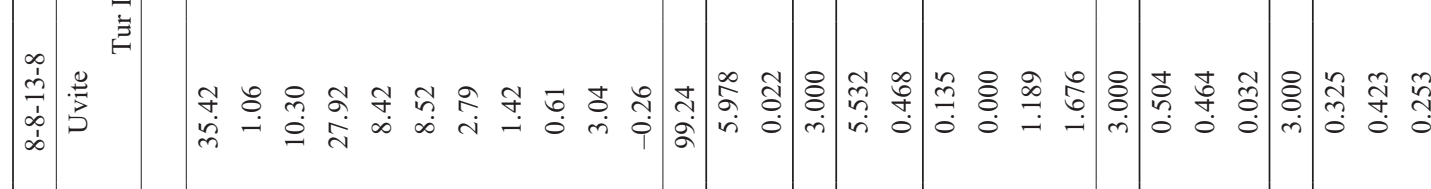

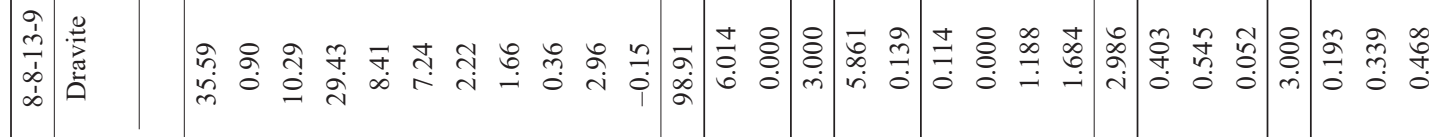

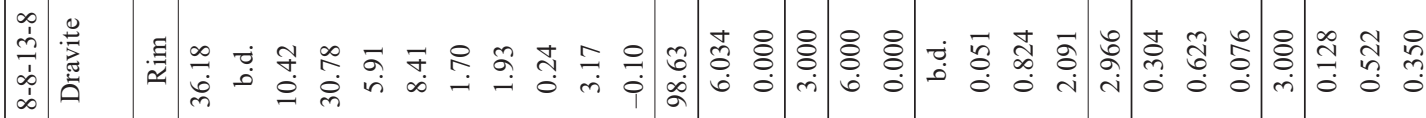

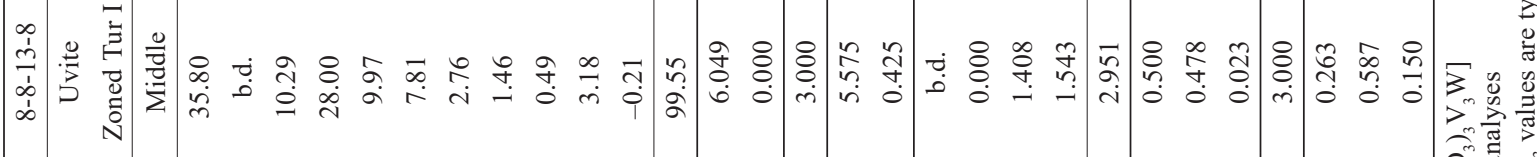

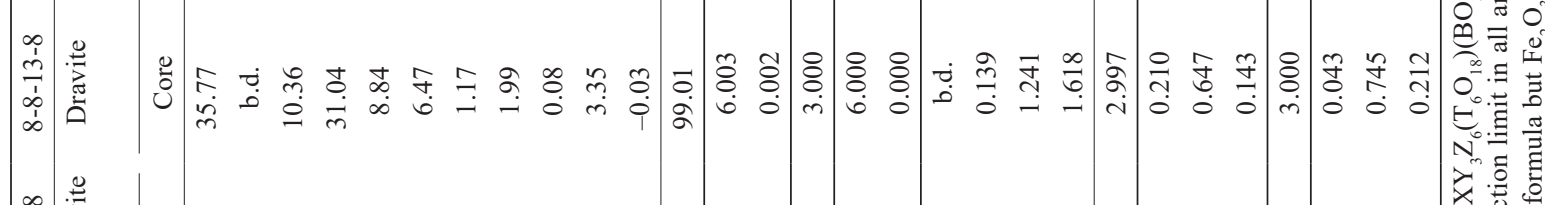

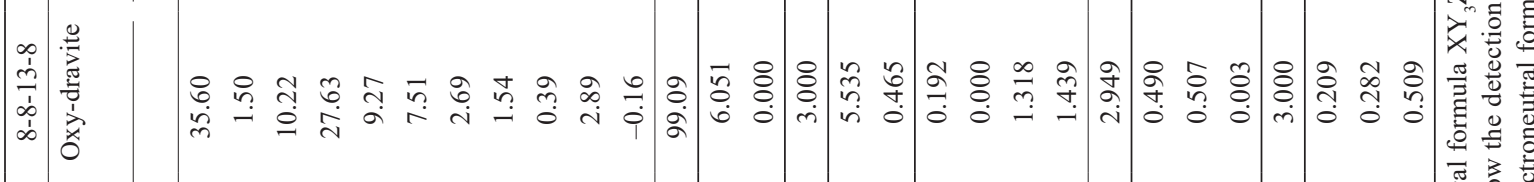

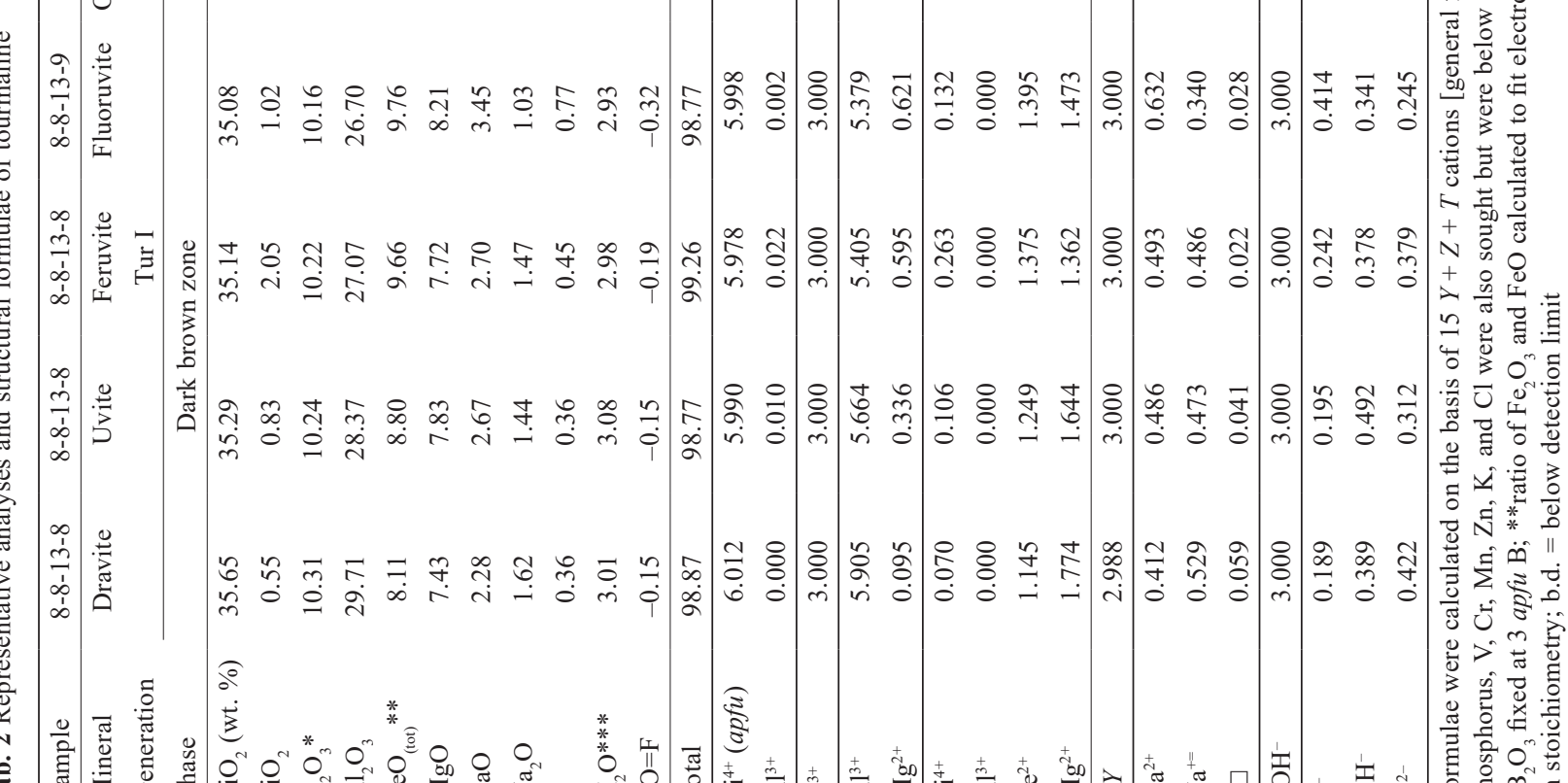




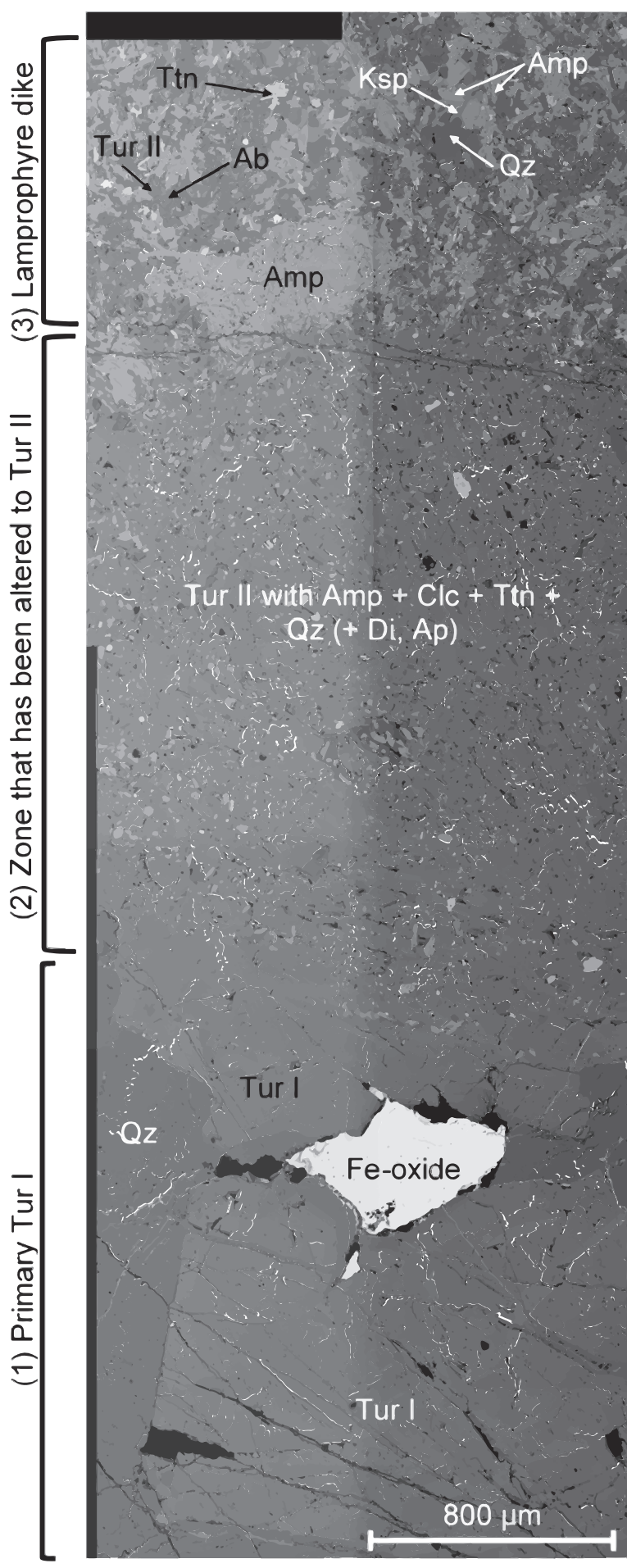

Fig. 4 A composite BSE image of sample 8-8-13-8 showing from bottom to top of the image: (1) Tur I at the margin of the lamprophyre dike, (2) a zone that has been altered to Tur II, and (3) the unaltered lamprophyre dike. In the altered zone (2), nearly all the original minerals in the lamprophyre dike have been altered to Tur II. The dike minerals present are mainly amphiboles (Amp; actinolite to magnesio-hornblende), clinochlore, titanite, and quartz with minor diopside and apatite. The slight change in shades of grey between the left and right sides of the image is due to stitching multiple BSE images together and is not reflective of a difference in composition.

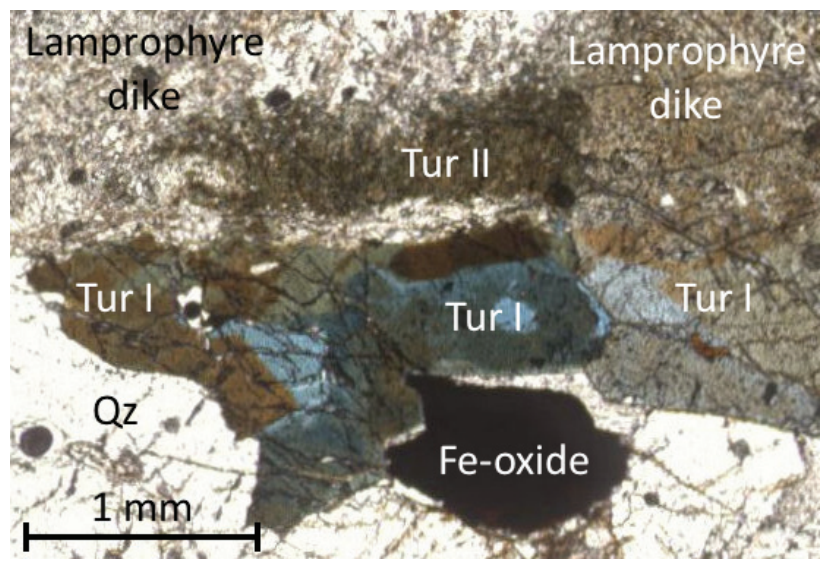

Fig. 5 A photo in plane-parallel transmitted light of tourmaline at the margin of a lamprophyre dike (sample 8-8-13-8). Tur I is mainly pale brown-green in color with patchy chemical zoning, but it can also be zoned with pale blue cores, a darker blue-green intermediate zone, and pale blue rims. The small dark brown zone close to the margin of the dike contains zones of feruvite. Tur II occurs within the lamprophyre dike and has partially replaced much of it.

apfu) was found in the dravitic outer rim of the single zoned crystal of Tur I, whereas the lowest total Al content observed was 5.321 apfu $\left(26.35\right.$ wt. $\left.\% \mathrm{Al}_{2} \mathrm{O}_{3}\right)$ in feruvite from Tur II. Titanium slightly increases from Tur I to Tur II, and is positively correlated with both $\mathrm{Ca}$ (Fig. 7b) and $\mathrm{Fe}_{\text {tot }}$ (Fig. 7c). Accordingly, the analyses with the highest Ti content are all feruvite from the small dark brown zones in Tur I (max. 2.05 wt. \% $\mathrm{TiO}_{2} ; 0.263$ apfu Ti) and within Tur II (max. 2.17 wt. \% $\mathrm{TiO}_{2} ; 0.278$ apfu Ti).

\section{Discussion}

\subsection{Origin of tourmaline assemblages}

The overall mineralogy of the studied dikes is consistent with calc-alkaline lamprophyres, specifically spessartites (Rock 1991): amphiboles are abundant and dominate over biotite mica, most minerals are Ca-rich, and $\mathrm{Mg}$ predominates over Fe. More specifically, amphiboles are magnesio-hornblende and actinolite, two species known to occur in calc-alkaline lamprophyres (Rock 1991). Phlogopite in the dikes contains high Ti (max. 4.13 wt. \% $\mathrm{TiO}_{2}$; average 3.34 wt. $\%, n=15$ ) and minor $\mathrm{F}$ (max. 1.08 wt. \%; average 0.66 wt. \%) with low $\mathrm{Cl}$ (max. 0.15 wt. \%; average 0.12 wt. \%). Phlogopite enriched in Ti and $\mathrm{F}$ is common in all lamprophyre varieties (Rock 1991).

The lamprophyre dikes being younger than the O'Grady Batholith (megacrystic hornblende granite phase $=95 \pm 1 \mathrm{Ma}$; Hunt and Roddick 1987) is consistent with other lamprophyre dikes associated with plutons of the Selwyn Plutonic Suite. Gordey and Anderson (1993) concluded that lamprophyre, aplite, porphyritic, and aplitic monzogranite dikes were younger than the Selwyn 
Plutonic Suite because they either cross-cut the plutons or are cospatial with them and intrude their contact aureoles. Therefore, we infer that the lamprophyre dikes are likely slightly younger than the O'Grady Batholith but older than the other units that were derived from the Batholith (aplite and pegmatite dikes, quartz veins).

Both Tur I and Tur II have high F contents, however the lamprophyre dikes do not contain any F-rich minerals. Phlogopite does host up to 1.08 wt. \% F, but the specific dike that the tourmaline is associated with contains only rare phlogopite. Fluorine-rich tourmaline occurs in the pegmatite and aplite dikes, reaching compositions of fluor-schorl, while tourmaline in the metasedimentary host rock and quartz veins is relatively poor in F (Scribner 2014). Therefore, the derivation of $\mathrm{F}$ should be external, with the only obvious source in the study area being in the pegmatite and aplite dikes.

From Tur I to Tur II, there is a change from alkali- to calcic-group tourmaline species and increase in Ti. This enrichment in $\mathrm{Ca}$ and $\mathrm{Ti}$ reflects the progressive reaction of $\mathrm{B}$-bearing fluids with $\mathrm{Ca}$ - and Ti-rich minerals in the lamprophyre dike; patchy zoning of the uvitic tourmaline can be attributed to a strongly selective $\mathrm{Ca}$ and Ti partitioning to the $-c$ pole of tourmaline crystals (e.g. Henry and Dutrow 1996; van Hinsberg et al. 2006). Calcium amphiboles (actinolite to magnesio-hornblende with up to 0.40 wt. $\% \mathrm{TiO}_{2}$, average 0.23 wt. $\%$ ) are one of the main minerals in the lamprophyre dikes, while calcic plagioclase is common in the matrix. The lamprophyre dike also contains titanite as a common accessory and rare phlogopite that is Ti-rich (up to 4.13 wt. $\% \mathrm{TiO}_{2}$ ). These minerals could have provided $\mathrm{Ca}$ and $\mathrm{Ti}$, allowing for the crystallization of evolved tourmaline

Fig. 6 Compositional variation of both tourmaline generations (I): a - Classification diagram based on the dominant occupancy of the $X$ site (Henry et al. 2011). There is a change from more alkali- to calcic-group species from Tur I to Tur II; $\mathbf{b}$ - General series of tourmaline species based on the occupancy of the $W$ site. There is a trend towards fluor- and oxy-species from Tur I to Tur II; $\mathbf{c}-$ Binary plot $\mathrm{Ca} /(\mathrm{Ca}+\mathrm{Na})$ vs. $\mathrm{Mg} /\left(\mathrm{Mg}+\mathrm{Fe}^{2+}\right)$. Most analyzed tourmalines are $\mathrm{Mg}$-dominant, but $\mathrm{Mg} /\left(\mathrm{Mg}+\mathrm{Fe}^{2+}\right)$ decreases from Tur I to Tur II.
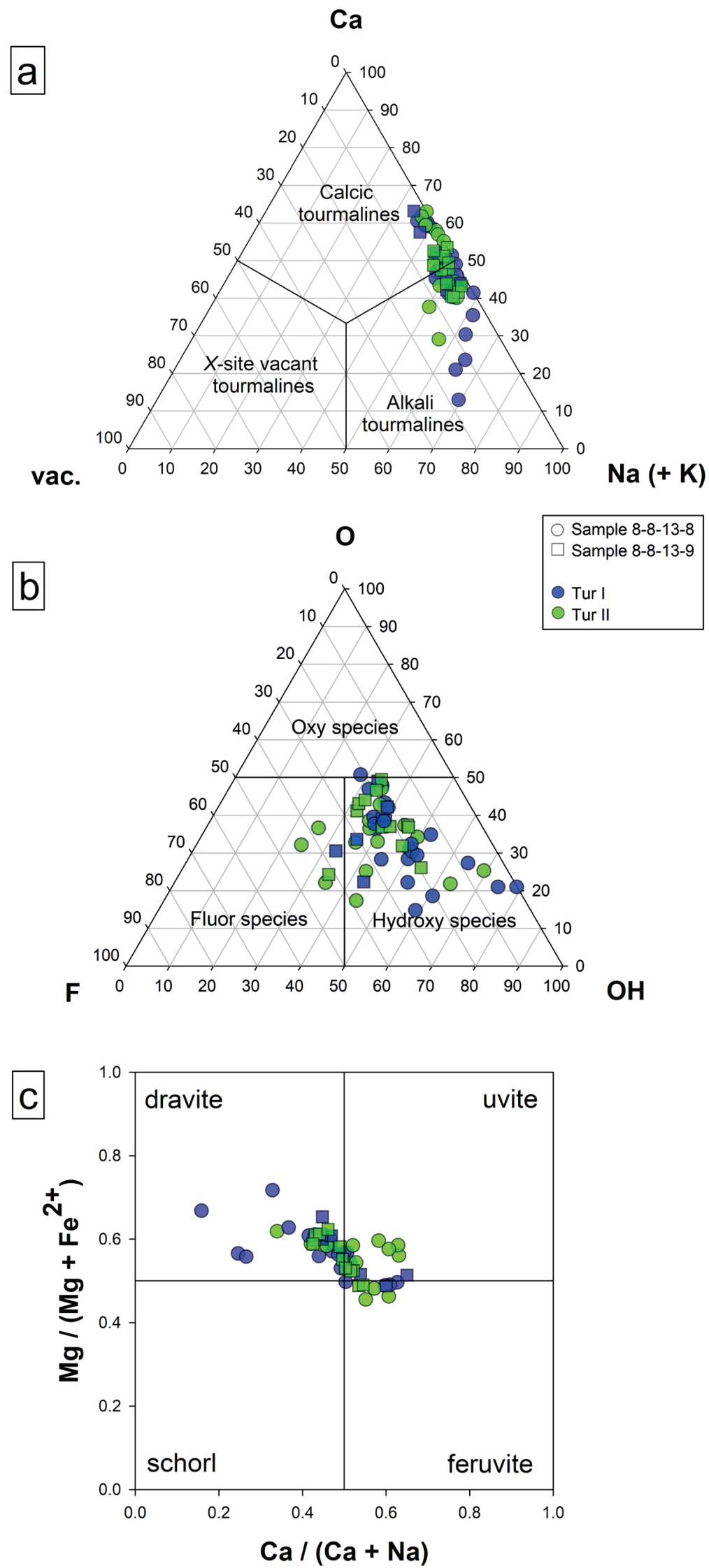

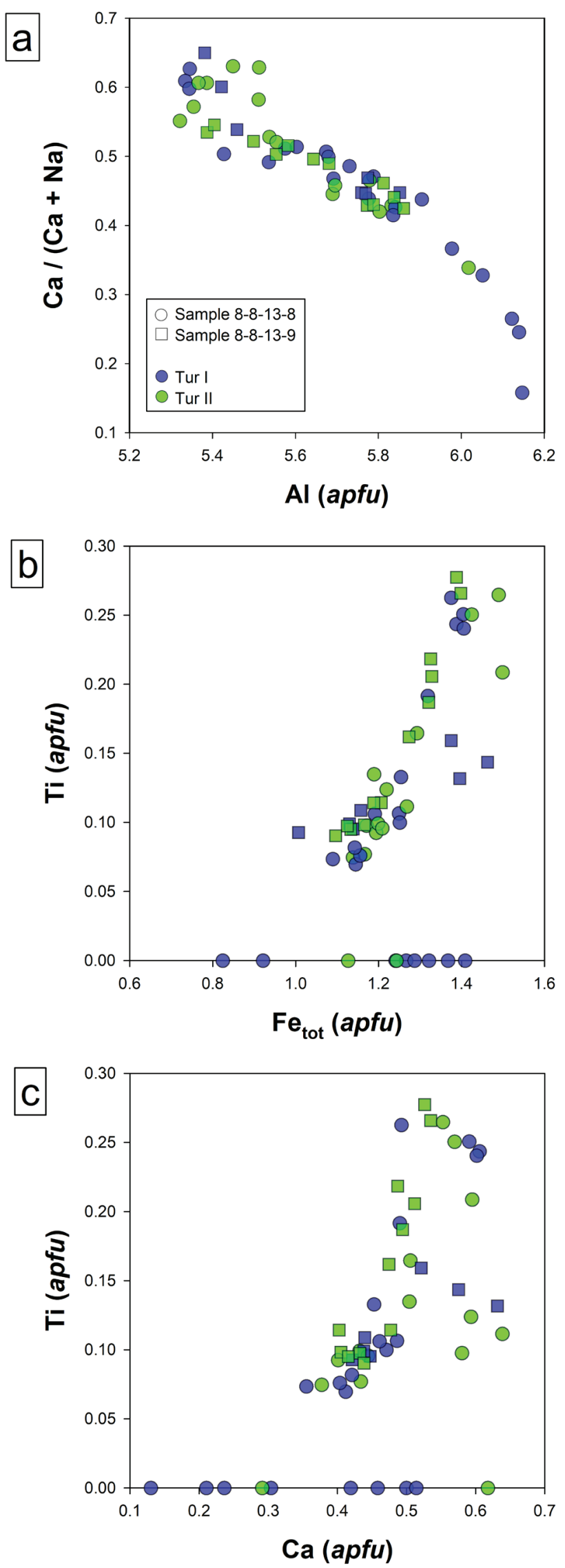

species such as feruvite at the margin of the lamprophyre dike.

All tourmaline species have low Al due to the lack of Al-rich minerals in the dike, but there is a decrease in Al content from Tur I to Tur II with progressive reaction of the B-bearing fluids with the lamprophyre dike. In the majority of tourmalines of both generations, $\mathrm{Mg}$ predominates over Fe, which is consistent with the presence of $\mathrm{Mg}$-dominant actinolite, magnesio-hornblende, and clinochlore in the host lamprophyre dike. The slight increase in Fe relative to $\mathrm{Mg}$ in Tur II is most likely due to the addition of Fe from a hydrothermal fluid (supported by presence of Fe-oxides in the quartz together with Tur I; Figs 4-5), and partially also due to $\mathrm{Mg} / \mathrm{Fe}$ partitioning between tourmaline and chlorite whereby tourmaline has a slight preference for Fe (Henry and Dutrow 1996; van Hinsberg et al. 2006).

\subsection{Uncertainties in tourmaline composition}

Several uncertainties must be pointed out regarding the compositions of the studied tourmalines. Despite very reasonable sums of tourmaline analyses, their stoichiometry is slightly offset from ideal since values for $\mathrm{Si}$ are sometimes slightly higher than 6 apfu (see Tab. 2 and Electronic Supplementary Material). However, the observed range of values (5.951-6.084 apfu, average 6.010 apfu) represents very small deviations, well within analytical error of $\mathrm{Si}$ (c. $2.6 \mathrm{rel} \%$ of the value). The deviations from ideal 6 apfu Si do not largely affect the formula classification, except slightly overestimated ${ }^{\mathrm{W}} \mathrm{O}$.

On the other hand, the ${ }^{\mathrm{W}} \mathrm{O}$ contents may very likely be largely underestimated due to unknown oxidation state of Fe. Since $\mathrm{Fe}_{\text {tot }}$ ranges between c. 1.1 and 1.5 apfu (Fig. 7), in the case of $\mathrm{Fe}^{3+} / \mathrm{Fe}_{\text {tot }}=0.25$ the ${ }^{\mathrm{W}} \mathrm{O}$ for all measured tourmalines would increase by 0.14-0.19 apfu. In most analyses it would be then higher than 0.5 apfu and the tourmaline classified as feruvite would potentially represent a new species (Mg-analogue of lucchesiite; see Bosi et al. 2017).

\subsection{Feruvite assemblages worldwide}

The metasomatic overprint of lamprophyre dikes near the O'Grady Batholith resulted in a mineral assemblage with Fe-rich uvite and feruvite. Iron-rich, Al-deficient calcic tourmalines (feruvite and lucchesiite) are relatively rare worldwide and form in specific environments. Gadas

Fig. 7 Compositional variation of both tourmaline generations (II): a - Al decreases from Tur I to Tur II with a change from alkali- to calcic-group species; $\mathbf{b}$ - The Ti content of tourmaline increases from Tur I to Tur II together with the $\mathrm{Fe}_{\text {tot }}$ content; $\mathbf{c}-\mathrm{Ti}$ also shows a positive correlation with $\mathrm{Ca}$. 
et al. (2014) distinguished three feruvite parageneses: 1) quartz-tourmaline veins in hydrothermally altered $\mathrm{Ca}$, $\mathrm{Al}, \mathrm{Fe}, \mathrm{Mg}$-rich host rocks; 2) exocontacts of granitic pegmatites hosted by meta-andesite and amphibolite; and 3) primitive pegmatites, sometimes affected by contamination from host skarn lithologies. The latter two parageneses may also host lucchesiite (Bosi et al. 2017). The studied occurrence belongs to the first group, where tourmaline forms at the expense of minerals in a mafic rock. It is also very similar to feruvite from the Sullivan mine, British Columbia, Canada (Jiang et al. 1996) that occurs in parts of a tourmalinite body adjacent to gabbro sills. In this case, feruvite formed by reaction of Fe-rich hydrothermal fluids with Ca-rich minerals in gabbro and the host rocks (Jiang et al. 1996). Similarly, Manning (1991) reported feruvite in host rocks adjacent to hydrothermal tourmaline (schorl-dravite) breccias in SW England and ascribed its origin to overprint of the host rocks by oxidizing fluids generated from granites.

\subsection{Ti-rich tourmaline}

Of the studied tourmaline, the highest $\mathrm{TiO}_{2}$ contents were found in feruvite (up to $2.17 \mathrm{wt}$. \%). This is similar to other feruvite localities; the feruvite holotype contains $2.2 \mathrm{wt}$. \% $\mathrm{TiO}_{2}$ (Grice and Robinson 1989), and even higher contents were found at the Sullivan mine, British Columbia (2.61 wt. \%; Jiang et al. 1996) and in uvite from tourmalinite in Piedmont Belt, South Carolina (3.25 wt. \%; Mittwede 1984). Similarly, lucchesiite (Gadas et al. 2014; Bosi et al. 2017) from both type localities contains up to 2.61 and 0.65 wt. $\% \mathrm{TiO}_{2}$, respectively. Feruvite associated with lucchesiite at Mirošov contains up to 1.35 wt. $\% \mathrm{TiO}_{2}$ (Gadas et al. 2014). In pegmatite tourmalines from Třebíč Pluton, high $\mathrm{TiO}_{2}$ contents (up to 3.80 wt. \%) were reported in Ca-rich, $\mathrm{Fe}^{3+}$-bearing, Al-deficient schorl-dravite (Novák et al. 2011; Čopjaková et al. 2013).

However, high $\mathrm{Ti}$ contents are not restricted to $\mathrm{Ca}-$ rich tourmalines: up to $4.70 \mathrm{wt} . \% \mathrm{TiO}_{2}(0.64$ apfu Ti $)$ was found in a bosiite-like mineral in the exocontact of an elbaite-subtype pegmatite by Flégr et al. (2016), and Žáček et al. (2000) reported up to 3.6 wt. \% $\mathrm{TiO}_{2}$ in povondraite-oxy-dravite-dravite with no or very low $\mathrm{Ca}$ contents. Konzett et al. (2012) found up to 3.42 wt. \% $\mathrm{TiO}_{2}$ in a single grain of Al-deficient, Fe-bearing dravite (with 5.2 apfu $\mathrm{Al}, 2.53$ apfu $\mathrm{Mg}, 0.73$ apfu $\mathrm{Fe}_{\text {tot }}$, and 0.23 $a p f u \mathrm{Ca}$ ) associated with $\mathrm{Ca}$,Ti-bearing dravite with elevated $\mathrm{Sr}\left(0.053\right.$ apfu; 0.56 wt. \% SrO). The highest $\mathrm{TiO}_{2}$ contents (up to 4.07 wt. $\% \mathrm{TiO}_{2}$ ) were encountered by Lottermoser and Plimer (1987) in the core of metasomatic dravite found within contact rocks included in a breccia diatreme at Umberatana, South Australia.

Therefore, high contents of $\mathrm{Ti}$ are typically restricted to Al-deficient tourmalines (e.g., Gadas et al. 2014) that can also have high $\mathrm{Fe}^{3+}$ (Flégr et al. 2016; Bosi et al. 2017), rather than to specific tourmaline species or groups; high $\mathrm{Ti}$ occurs in both calcic and sodic tourmalines. On the other hand, the combination of high $\mathrm{Fe}$ contents with significant $\mathrm{Mg}$ at the $Z$ site is a feature common to most Ti-rich tourmaline occurrences. We suggest that this compositional preference is caused by the small ionic radius of the $\mathrm{Ti}^{4+}$ cation, compared to relatively large cations such as $\mathrm{Fe}^{2+}, \mathrm{Mg}^{2+}$, and $\mathrm{Fe}^{3+}$, whereby the incorporation of $\mathrm{Ti}^{4+}$ partially reduces strain in the tourmaline structure.

\section{Conclusions}

1) The calc-alkaline lamprophyre dikes near the O'Grady Batholith are hosted by tourmalinized sedimentary rocks. The lamprophyre dikes are likely younger than the O'Grady Batholith, assuming that the relative ages of the Batholith and the associated lamprophyre dikes are the same as for other plutons in the Selwyn Plutonic Suite. In any case, the cross-cutting relationships indicate that the lamprophyre dikes are older than aplite and pegmatite dikes, as well as the tourmaline-bearing quartz veins that were all derived from the O'Grady Batholith.

2) Two generations of tourmaline are associated with one of the lamprophyre dikes. Tur I occurs along the margin of the dike and Tur II occurs within an altered lamprophyre zone still near its margins. Dravite is common in both generations, but the proportion of more evolved tourmaline species, namely uvite, feruvite, and fluor-uvite, increases in Tur II. Fluor-uvite occurs in both generations of tourmaline. The high $\mathrm{F}$ contents of some tourmaline species from both generations suggests that they crystallized from fluids derived from nearby aplite and pegmatite dikes.

3) The lamprophyre dike represented a unique geochemical environment that allowed for the crystallization of uncommon tourmaline species. The progressive reaction of metasomatic fluids with the $\mathrm{Ca}-, \mathrm{Mg}-\mathrm{Fe}-$, and Ti-bearing minerals in the dike presumably resulted in the crystallization of increasingly $\mathrm{Ca}-, \mathrm{Fe}-$, and Ti-rich tourmaline. All tourmaline is Al-deficient due to the lack of Al-rich minerals in the dike. The most evolved compositions of tourmaline associated with the lamprophyre dike are feruvite with up to $2.17 \mathrm{wt}$. $\% \mathrm{TiO}_{2}$, and fluor-uvite with up to 0.84 wt. $\% \mathrm{~F}$.

4) Mutual relationships of tourmaline assemblages in the area are rather complex and desire further clarification using modern methods. The authors are currently preparing a manuscript on the regional tourmaline composition including the isotopic signature of tourmaline from all rock types and units. 
Acknowledgments. This manuscript greatly benefited from constructive reviews by Robert Trumbull and Petr Bačík, as well as editor Vojtěch Janoušek. The authors thank Ronald Peterson and Brad Wilson for aiding in field work to collect the samples. We also thank guest editor Milan Novák for editorial handing. The research was supported by NSERC Discovery Grant RGPIN-2015-06434 to LAG and research project GA-17-17276S to JC.

Electronic supplementary material. Complete mineral analyses for this paper are available online at the Journal web site (http://dx.doi.org/10.3190/jgeosci.259).

\section{References}

Anderson RG (1983) Selwyn Plutonic Suite and its relationship to tungsten skarn mineralization, southeastern Yukon and District of Mackenzie. Current Research, Part B. Geological Survey of Canada, Paper 83-1B: pp 151-163

Bosi F, Skogby H, Ciriotti Me, Gadas P, Novák M, Cempírek J, Všianský D, Filip J (2017) Lucchesiite, $\mathrm{CaFe}^{2+}{ }_{3} \mathrm{Al}_{6}\left(\mathrm{Si}_{6} \mathrm{O}_{18}\right)\left(\mathrm{BO}_{3}\right)_{3}(\mathrm{OH})_{3} \mathrm{O}$, a new mineral species of the tourmaline supergroup. Mineral Mag 81: 1-14

Cempírek J, Houzar S, Novák M (2008) Complexly zoned niobian titanite from hedenbergite skarn at Písek, Czech Republic, constrained by substitutions $\mathrm{Al}(\mathrm{Nb}$, $\mathrm{Ta}) \mathrm{Ti}_{-2}, \mathrm{Al}(\mathrm{F}, \mathrm{OH})(\mathrm{TiO})_{-1}$ and $\mathrm{SnTi}_{-1}$. Mineral Mag 76: 1293-1305

Čopjaková R, ŠKoda R, VašInová-Galiová M, Novák M (2013) Distributions of Y+ REE and Sc in tourmaline and their implications for the melt evolution; examples from NYF pegmatites of the Třebíc Pluton, Moldanubian Zone, Czech Republic. J Geosci 58: 113-131

Ercit TS, Groat LA, Gault RA (2003) Granitic pegmatites of the O'Grady Batholith, N.W.T., Canada: a case study of the evolution of the elbaite subtype of rare-element granitic pegmatite. Canad Mineral 41: 117-137

Ertl A, Hughes JM, Prowatke S, Ludwig T, Prasad PSR, Brandstätter F, Körner W, Schuster R, Pertlik F, MarsChall H (2006) Tetrahedrally coordinated boron in tourmalines from the liddicoatite-elbaite series from Madagascar: structure, chemistry, and infrared spectroscopic studies. Amer Miner 91: 1847-1856

FlÉGr T, NovÁK M, Cempírek J (2016) New occurrence of bosiite in the Rečice pegmatite, Czech Republic. In: Gadas P (ed) New Minerals and Mineralogy in the $21^{\text {st }}$ Century, International Scientific Symposium Jáchymov 2016. Minera Analytica, Prague, pp 23-25

Gadas P, Novák M, Cempírek J, Filip J, VašInová-Galiová M, GROAT LA, VŠIANSKÝ D (2014) Mineral assemblages, compositional variation, and crystal structure of feruvitic tourmaline from a contaminated anatectic pegmatite at
Mirošov near Strážek, Moldanubian Zone, Czech Republic. Canad Mineral 52: 285-301

GoRDEY SP (1992) Geology, Little Nahanni River, Northwest Territories-Yukon Territory [map]. 1:250,000. Geological Survey of Canada, Map 1762A

Gordey SP, ANDERSON RG (1993) Evolution of the northern Cordilleran miogeocline, Nahanni map area (105I), Yukon and Northwest Territories. Geological Survey of Canada, Memoirs 428. Canada Communications Group, Ottawa, pp 1-214

Grice JD, Robinson GW (1989) Feruvite, a new member of the tourmaline group, and its crystal structure. Canad Mineral 27: 199-203

Groat LA, Ercit TS (1996) Granitic Pegmatites in NorthWestern Canada. Department of Indian and Northern Affairs Canada, Open File 1996-3, pp 1-38

HaRt CJR, BAKER T, BURKe M (2000) New exploration concepts for country-rock-hosted, intrusion-related gold systems: Tintina gold belt in Yukon. In: TUCKER TL, Sмiтh MT (eds) The Tintina Gold Belt: Concepts, Exploration and Discoveries. British Columbia and Yukon Chamber of Mines Special Volumes 2, pp 145-172

Hawthorne FC, Dirlam DM (2011) Tourmaline the indicator mineral: from atomic arrangement to Viking navigation. Elements 7: 307-312

Henry D, Dutrow B (1996) Metamorphic tourmaline and its petrologic applications. In: GREw ES, ANOvitz LM (eds) Boron: Mineralogy, Petrology and Geochemistry. Mineralogical Society of America Reviews in Mineralogy 33: 503-557

Henry D, Novák M, Hawthorne FC, Ertl A, Dutrow BL, Uher P, Pezzotta F (2011) Nomenclature of the tourmaline-supergroup minerals. Amer Miner 96: 895-913

Hunt PA, RoDDICK JC (1987) A compilation of K-Ar ages. Radiogenic Age and Isotopic Studies: Report 1. Ministery of Supply and Services Canada, Paper 87-2: pp 143-204

Jiang S-Y, Palmer MR, McDonald AM, SLack JF, Leitch CHB (1996) Feruvite from the Sullivan $\mathrm{Pb}-\mathrm{Zn}-\mathrm{Ag}$ deposit, British Columbia. Canad Mineral 34: 733-740

Konzett J, Krenn K, Hauzenberger CH, Whitehouse M, HoInKes G (2012) High-pressure tourmaline formation and fluid activity in $\mathrm{Fe}$-Ti-rich eclogites from the Kreuzeck Mountains, Eastern Alps, Austria. J Petrol 53: 99-125

Leake Be, Woolley AR, Birch WD, Burke EAJ, Ferraris G, Grice JD, Hawthorne FC, Kisch HJ, Krivovichev VG, Schumacher JC, StepheNSON NCN, WhitTAKER EJW (2004) Nomenclature of amphiboles: additions and revisions to the International Mineralogical Association's amphibole nomenclature. Mineral Mag 68: 209-215

LotTermoser BG, Plimer IR (1987) Chemical variation in tourmalines, Umberatana, South Australia. Neu Jb Mineral, Mh 7: 314-326 
MAIR JL, HART CJR, StePhens JR (2006) Deformation history of the northwestern Selwyn Basin, Yukon, Canada: implications for orogen evolution and mid-Cretaceous magmatism. Geol Soc Am Bull 118: 304-323

MANNING DAC (1991) Chemical variation in tourmalines from south-west England. Proc Ussher Soc 7: 327-332

MitTwede SK (1984) Significance of tourmaline compositions from the inner Piedmont geologic belt of South Carolina. Southeast Geol 24: 207-210

NovÁK M, ŠKoda R, Filip J, MaceK I, VACUloviČ T (2011) Compositional trends in tourmaline from intragranitic NYF pegmatites of the Třebíč Pluton, Czech Republic: an electron microprobe, Mössbauer and LA-ICP-MS study. Canad Mineral 49: 359-380

Pouchou JL, PichoIr F (1985) "PAP" ( $\varphi \rho Z)$ procedure for improved quantitative microanalysis. Microbeam Anal 20: 104-106

Rock NMS (1991) Lamprophyres. Blackie and Son Ltd, Glasgow and London, pp 1-285

SCRIBNER ED (2014) Chemical Evolution of Tourmaline from a Granitic Pegmatite in the Nááts'ihch'oh Igneous
Complex, Northwest Territories, Canada. Unpublished BSc thesis, Queen's University, Kingston, pp 1-52

Scribner ED, Groat LA, Peterson RC, Cempírek J, WiLSON BS, JoY B (2014) Chemical evolution of tourmaline from a granitic pegmatite in the Nááts'ihch'oh Igneous Complex, Northwest Territories, Canada. Geological Society of America 2014 Annual Meeting, Vancouver, Canada, pp 1-694

van Hinsberg VJ, Schumacher JC, Kearns S, Mason PRD, FrAnz G (2006) Hourglass sector zoning in metamorphic tourmaline and resultant major and trace element fractionation. Amer Miner 91: 717-728

van Hinsberg VJ, Henry DJ, Marschall HR (2011) Tourmaline: an ideal indicator of its host environment. Canad Mineral 49: 1-16

Whitney DL, Evans BW (2010) Abbreviations for names of rock-forming minerals. Amer Miner 95: 185-187

ŽÁČEK V, FrÝdA J, Petrov A, HyRŠL J (2000) Tourmalines of the povondraite-(oxy)dravite series from the cap rock of meta-evaporite in Alto Chapare, Cochabamba, Bolivia. J Czech Geol Soc 45: 3-12 